\title{
MODEL KURIKULUM MILLER-SELLER DAN PENGEMBANGANNYA DALAM INSTRUCTIONAL DESIGN
}

Syafruddin Nurdin

Fakultas Tarbiyah IAIN Imam Bonjol Padang

\begin{abstract}
In order to curriculum can be implemented as well as in classroom lecture, therefore a syllabus should be developed become instructional design. Instructional design containt of components; standard competence, basic of competence, indicator of competence, subject of lecture, and it's materials, learning experience (teaching and learning strategy), media, evaluation, and reference. Instructional design is activity projection that will be done by lecturer in learning activity.
\end{abstract}

Key Words: Model Kurikulum, Miller-Seller, pengambangan, instructional design.

\section{PENDAHULUAN}

Model kurikulum Miller-Seller merupakan pengembangan kurikulum kombinasi dari model transmisi (Gagne) dan model transaksi (Taba’s \& Robinson). Miller Seller (1985) mendefinisikan kurikulum sebagai rangkaian interaksi sadar (intentional interactions) yang bersifat eksplisit maupun implicit yang didesain untuk memfasilitasi belajar siswa dan perkembangan siswa, serta untuk memberikan arti (meaning) pada pengalaman.

Interaksi yang terjadi bisa antara guru dengan siswa, antara siswa dengan siswa, antara siswa dengan bahan pelajaran, antara siswa dengan computer, dan bahkan antara siswa dengan masyarakat. Interaksi terjadi pada level yang berbeda pula untuk level yang paling bawah dimana siswa hanya menyerap informasi factual dari suatu buku pelajaran saja, pada level yang lebih tinggi interaksi antara siswa dengan guru dalam kegiatan belajar mengajar dengan pendekatan pemecahan masalah, dan pada level yang paling tinggi siswa mengalami. Misalnya,melalui puisi eksperimen ilmiah, atau musik, merangsang kesadaran baru, persepsi baru atau pemahaman kognitif dialog antara siswa dan guru berlangsung dalam hubungan (saya-anda) atau suatu mutualitas terbuka antara siswa dan guru.

Guru adalah agen pengembang kurikulum, dan untuk memudahkan guru dalam melaksanakan tugasnya sebagai pengembang kurikulum dalam mengembangkan suatu perspektif kurikulum yang lebih jelas, maka guru dituntut untuk memahami hubunganhubungan antara teori kurikulum (dasar filosofis, psikologis, dan sosial) dan praktek 
kurikulum (pengembangan implementasi, evaluasi).

Menurut Miller-Seller (1985: 225226) ada tiga orientasi kurikulum yang mempengaruhi terjadinya perbedaan dalam program-program kurikulum. Pengembangan, implementasi, dan evaluasi kurikulum hendaknya dilakukan sesuai dengan posisi atau orientasi kurikulum yang mendasarinya.

\section{MODEL PENGEMBANGAN KURIKULUM MILLER- SELLER}

Miller dan Seller mencoba menyusun suatu model yang lebih komprehensif berdasarkan pandangan mereka tentang kurikulum. Miller dan Seller (1985) mengemukakan bahwa proses pengembangan kurikulum adalah rangkaian kegiatan yang dilakukan secara terus menerus. Seller memandang bahwa pengembangan kurikulum harus dimulai dari menentukan orientasi kurikulum, yakni kebijakan-kebijakan umum, misalnya arah dan tujuan pendidikan, pandangan tentang hakikat belajar dan hakikat anak didik, pandangan tentang keberhasilan implementasi kurikulum dan lain sebagainya.

\section{Orientasi Kurikulum}

Pengembangan kurikulum berdasarkan suatu orientasi. Orientasiini mencerminkan pandangan filsafat, psikologi dan teori belajar, tentang masyarakat, pandangan tentang dunia atau paradigma yang dianut para pembina.Berdasarkan orientasi itu selanjutnya dikembangkan kurikulum menjadi pedoman pembelajaran, diimplementasikan dalam proses pembelajaran dan dievaluasi. Hasil evaluasi itulah kemudian dijadikan bahan dalam menentukan orientasi, begitu seterusnya hingga membentuk siklus.

Orientasi pengembangan kurikulum menurut Miller-Seller menyangkut enam aspek, yaitu:

1) Tujuan pendidikan menyangkut arah kegiatan pendidikan, artinya hendak dibawa kemana siswa yang kita didik itu.

2) Pandangan tentang anak, apakah anak dipandang sebagai organisme yang aktif atau pasif.

3) Pandangan tentang proses pembelajaran, apakah proses pembelajaran itu dianggap sebagai proses transformasi ilmu pengetahuan atau mengubah perilaku anak.

4) Pandangan tentang lingkungan, apakah lingkungan belajar harus dikelola secara formal atau secara bebas yang dapat memungkinkan anak bebas belajar.

5) Konsepsi tentang peranan guru, apakah guru harus berperan sebagai instruktur yang bersifat otoriter atau guru dianggap sebagai fasilitator yang siap memberi bimbingan dan bantuan pada anak untuk belajar.

6) Evaluasi belajar, apakah untuk mengukur keberhasilan ditentukan dengan tes atau nontes.

Menurut Miller-Seller ada tiga orientasi kurikulum, yakni:

a). Orientasi transmisi (transmission orientation) 
Kurikulum pada orientasi ini menekankan pada isi atau materi ajaran, isinya bersumber pada disiplin ilmu yang terstruktur/sistematis, guru berfungsi sebagai pemberi arahan langsung dan penyampai ilmu, teknologi, dan nilai sehingga harus menguasai materi ajar dengan baik. Sementara siswa harus bekerja keras sebagai penerima materi ajar, sehingga proses belajar yang terjadi adalah ekspositori dan evaluasi pembelajaran menggunakan tradisional achievement seperti tes, uraian, multiple objective, dan sebagainya. Pendidikan adalah ilmu yang harus dikuasai siswa dalam kompetensi-kompetensi yang dapat diukur, dengan demikian, tujuan pendidikan yang digunakan adalah penguasaan mata pelajaran dan norma-norma sosial yang sifatnya pengetahuan (Miller \& Seller: 1985: 17-60).

\section{b). Orientasi transaksi (transaction orientation)}

Dalam orientasi transaksi, antara kurikulum dan siswa saling memberi pengaruh. Individu dipandang sebagai seseorang yang rasional dan memiliki kemampuan inteligensi untuk menyelesaikan masalah. Pendidikan dipandang sebagai dialog antara siswa dan kurikulum, dimana siswa membangun pengetahuan melalui proses dialog, sebab siswa dipandang mempunyai keterampilan seperti kemampuan berfikir.

Elemen inti dari transaksi ini adalah terletak pada strategi kurikulum yang membantu pemecahan masalah (orientasi proses kognitif), aplikasi keterampilan memecahkan masalah didalam kontek sosial secara umum dan didalam kontek proses demokratik (orientasi kewarganegaraan demokratis) dan pengembangan keterampilan kognitif didalam berbagai disiplin akademis. Paradigma filsafat scientific merupakan metode ilmiah yang dipakai dalam orientasi transaksi ini. Pusat orientasi transaksi ini adalah ide yang diambil dari psikologi perkembangan dimana siswa harus diberi kesempatan menyelidiki dunia fisik, moral, dan sosial. Lingkungan belajar, harus kaya dengan beragam materi dan ide sehingga memungkinkan penyelidikan terhadap problem yang bervariasi (Miller \& Seller: 1985: 62-114)

\section{c). Orientasi transformasi (transformation orientation)}

Dalam orientasi transformasi ini, kurikulum dan siswa saling menyentuh (interpenetrate) secara holistik. Transformasi ditujukan pada pengembangan pribadi dan perubahan sosial, sehingga dikembangkan pola hubungan yang dekat antar individu dan masyarakat. Untuk mendukungnya, secara spesifik, model ini menekankan pada pengajaran berbagai keahlian untuk memajukan transformasi pribadi dan sosial, visi perubahan sosial sebagai perkembangan yang harmonis dengan lingkungan, dan hubungan dimensi spiritual dengan lingkungan (orientasi transpersonal). Teori pendidikan yang digunakan adalah pendidikan progresifdan romantik, dengan model kurikulum humanistik.

Orientasi ini didasarkan pada dua pemikiran,yaitu:(1). Elemen romantik yang menghasilkan argumen bahwa anak pada dasarnya bagus dan pendidik harus 
memungkinkan potensi alami anak untuk berkembang dengan sedikit campur tangan;(2). Orientasi perubahan sosial yang berargumen bahwa pendidik harus mengambil pandangan kritis yang lebih terhadap peran sekolah dalam masyarakat sehingga sekolah tidak sekedar tertarik secara ekonomi, tapi juga berperan dalam perubahan sosial politik. Transformasi beranggapan bahwa pendidikan yang berhasil adalah pendidikan yang mampu mengaktualisasikan diri (Miller \& Seller:1985: 117-141).

\section{Tujuan}

Sesudah pemantapanorientasi kurikulum perlu pengembangan tujuan, baik yang bersifat developmental, maupun spesifik. Tujuan umum mencerminkan gambaran peserta didik dan gambaran masyarakat. Gambaran ini harus jelas dirumuskan. Sesudah gambaran ini ditetapkan, maka kemudian harus disusun konsep pengembangan yang sesuai dengan visi. Setiap tujuan umum harus dapat dijabarkan dalam program-program yang ditujukan kepada murid dalam berbagai tingkat perkembangan.

Tujuan mempunyai tiga tingkatan, yaitu (1) Tujuan tanggung jawab social, (2) Tujuan yang bersifat pengembangan: siswa mengenal lapangan pembangunan masyarakat dan berpartisipasi dalam proyek pembanguna, (3) Tujuan instruksional: siswa mengembangkan keterampilan yang diperlukan dalam proyekproyek pembangunan masyarakat (Miller \& Seller, 1985: 226-227).

\section{Pengalaman belajar dan strategi mengajar}

Dalam model Miller dan Seller guru perlu memilih model posisi yang sesuai. Pertimbangan dalam memilih strategi adalah sebagai berikut, (1) Keseluruhan model sejalan dengan tujuan, (2) Struktur model serasi dengan kebutuhan siswa; ada yang menghendaki banyak pengarahan ada yang kurang pengarahan, ada yang menghendaki lebih bebas, (3) Guru mendapat penataran (in service training) yang menunjang penerapan model, (4) Sumber untuk pelaksanaan model tersedia (Miller \& Seller, 1985: 227-228).

\section{Implementasi}

Hamalik mengemukakan bahwa "Implementasi merupakan suatu proses penerapan ide, konsep, kebijakan, atau inovasi dalam bentuk tindakan praktis sehingga memberi dampak, baik berupa perubahan pengetahuan, keterampilan, maupun sikap". Miller dan Seller mengemukakan bahwa "Implementasi kurikulum merupakan suatu penerapan konsep, ide, program, atau tatanan kurikulum ke dalam praktek pembelajaran atau aktivitas-aktivitas baru, sehingga terjadi perubahan pada sekelompok orang yang diharapkan berubah".

Miller dan Seller mengemukakan bahwa ada tiga pendekatan yang umum tentang implementasi, yaitu: (1) Implementasi didefinisikan sebagai suatu peristiwa atau kejadian. Peristiwa yang terjadi sebagai suatu kegiatan pengembangan profesional, ketika dokumen dari suatu program barudibagikan 
kepada para guru; (2) Pendekatan implementasi yang ditekankan pada proses interaksi antara pengembang kurikulum dengan para guru; (3) Memandang dan mengakui bahwa implementasi sebagai bagian dari komponen kurikulum (Miller \& Seller: 1985: 228).

\section{Evaluasi}

Secara garis besar model pengembangan kurikulum Miller-Seller dapat dilukiskan seperti pada gambar 1 .

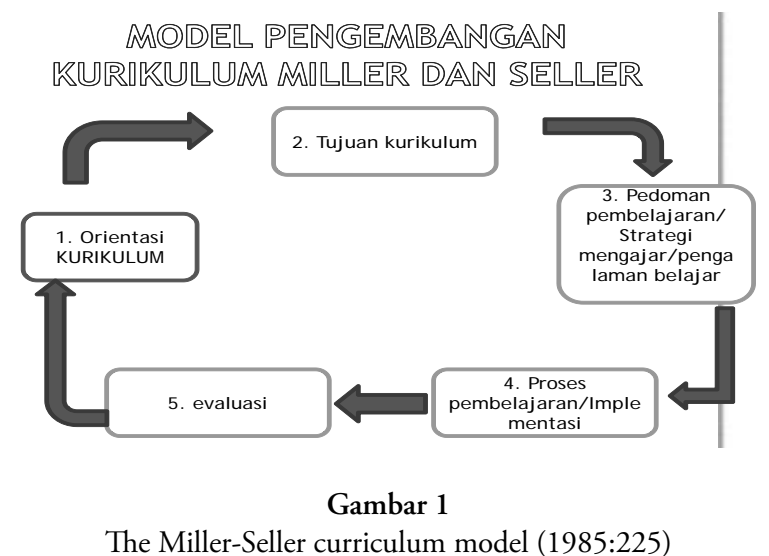

Menurut model Miller-Seller ini prosedurprosedur evaluasi dalam pengembangan kurikulum hendaknya merefleksikan orientasi seseorang. Prosedur evaluasi yang dibakukan pada umumnya tidak sesuai dengan kurikulum transformasi. Sebaliknya kurikulum transmisi umumnya menggunakan teknik-teknik evaluasi yang berstruktur dalam menilai kesesuaian antara pengalaman -pengalaman belajar dan strategi mengajar dengan tujuan kurikulum (Miller \& Seller, 1985: 228-230).

\section{PENGEMBANGAN DAN APLIKASI MODEL KURIKULUM MILLER-SELLER DALAM PENYUSUNAN INSTRUCTIONAL DESIGN(SAP)}

Sebagaimana dijelaskan oleh John P. Miller and Wayne Seller dalam bukunya Curriculum: Perspective and Practice (1985: 225) bahwa model Pengembangan Kurikulum MillerSeller terdiri dari lima langkah utama, yaitu: (1) klarifikasi orientasi, (2) pengembangan tujuan, (3) pedoman pembelajaran/ pengalaman belajar, (4) implementasi/proses, dan (5) evaluasi.

Hamalik (2011: 60), mengurutkan langkah-langkah pengembangan kurikulum Miller-Seller, sebagai berikut: (1). Klarifikasi orientasi kurikulum; (a). transmisi, (b). transaksi, (c). transformasi; (2). Pengembangan tujuan; (a). tujuan umum (aims), (b). tujuan pengembangan (goals), tujuan instruksional (objectives); (3). Identifikasi model mengajar (strategi mengajar) sesuai dengan tujuan umum dan orientasi kurikulum; (4). Pengembangan rencana implementasi, dan (5). Pengembangan evaluasi sesuai dengan tujuan dan orientasi.

Meskipun terdapat beberapa model pengembangan kurikulum dengan bermacammacam variasi dan langkah pengembangannya, tapi pada dasarnya secara teoretik masingmasing model tersebut mengikuti prosedur pengembangan dari empat komponen utama kurikulum, yang merupakan jawaban dari pertanyaan mendasar sebagaimana dikemukakan oleh Tyler (Laurie Brady: 1992, 69), sebagai berikut: (1). What educational purposes should the school seek to attain? (2). What educational experiences can be provided that are likely to attain these purposes? (3). How can these educational experiences be effectively 
organized? (4). How can we determined whether these purposes are being attained?

Keempat jawaban dari pertanyaan di atas sekaligus menjadi langkah utama pengembangan kurikulum, termasuk model pengembangan kurikulum Miller-Seller. Sebagaimana dinyatakan Laurie Brady (1992: 69) "The four steps are sometime simplified to read objectives, content, method and evaluation".

Berdasarkan hal tersebut di atas dan sesuai dengan tujuan tulisan ini, maka selanjutnya penulis mengemukakan pengembangan dan aplikasi model kurikulum Miller-Seller dalam penyusunan Instructional Design atau Satuan Acara Perkuliahan (SAP).

Instructional Design atau SAP yang dikembangkan ini, klasifikasi orientasi kurikulumnya adalah antara "transmission dan transaction (cirinya dapat dilihat pada uraian orientasi berikut).

\section{SATUAN ACARA PERKULIAHAN (SAP)}

Mata Kuliah : Pengembangan Kurikulum

Topik : Asas Psikologis

Sub-Topik : Teori-Teori Belajar

Utama

SKS : 3 (tiga) SKS

Jurusan/Prodi : PAI \& KI

\section{A. Standar Kompetensi}

Memahami dan Mengenal Teori-Teori Belajar Utama, Asumsi Dasar dan Karakteristik Masing-Masingnya serta Mengerti Hubungan/Keterkaitan Teori Perkembangan Kognitif (Cognitive Growth)
Jean Piaget dengan Pengembangan Kurikulum/Pembelajaran.

\section{B. Kopetensi Dasar}

1. Menjelaskan Pengertian / Konsep masing-masing Teori Belajar Utama

2. Mengemukakan Pandangan masingmasing Teori Belajar Utama Tentang "Belajar"

3. Membandingkan Asumsi Dasar Teoriteori Belajar Utama

4. Mendeskripsikan Perbedaan Karakteristik Teori-teori Belajar Utama

5. Menjelaskan Hubungan Teori Perkembangan Kognitif Jean Piaget dengan Pengembangan Kurikulum/ Pembelajaran

\section{Indikator Kopetensi}

1. Mampu menjelaskan pengertian masing-masing Teori Belajar Utama

2. Mampu menyebutkan tokoh-tokoh (pemuka) dari masing-masing Teori Belajar Utama

3. Mampu menguraikan aliran / cabangcabang Teori Belajar Utama

4. Mampu mengidentifikasi pandangan masing-masing Teori Belajar Utama tentang "belajar".

5. Mampu menyebutkan unsur-unsur penting dalam belajar menurut masingmasing Teori Belajar Utama

6. Mampu menjelaskan prinsip-prinsip belajar menurut masing-masing Teori Belajar Utama. 
7. Mampu menganalisis dampak dari pandangan masing-masing Teori Belajar Utama terhadap pengembangan kurikulum / pembelajaran

8. Mampu mengemukakan contohcontoh praktek pendidikan yang dipengaruhi oleh masing-masing Teori Belajar Utama

9. Mampu membedakan karakteristik masing-masing Teori Belajar Utama

10. Mampu membandingkan asumsi dasar masing-masing Teori Belajar Utama

11. Mampu menggambarkan hubungan dan keterkaitan antara Teori Perkembangan KognitifJean Piaget dengan pengembangan kurikulum / pembelajaran

12. Mampu menganalisis pentingnya penguasaan Teori-Teori Belajar Utama bagi calon guru, guru / staf pengajar.

13. Mampu menerapkan prinsip-prinsip belajar dari masing-masing Teori Belajar Utama ke dalam praktek pembelajaran di kelas

14. Mampu mengevaluasi / menilai kekuatan dan kelemahan masingmasing Teori Belajar Utama.

\section{Materi Kuliah Dan Uraiannya}

Teori-teori belajar utama, yaitu: (a) Ilmu Jiwa Daya (Faculty Psychology), (b) Asosiasi, dan (c) Gestalt

a. Pengertian Teori Belajar Ilmu Jiwa Daya

b. Pengertian Teori Belajar Asosiasi

c. Pengertian Teori Belajar Gestalt d. Tokoh-tokoh (pemuka) dari masingmasing teori belajar

\section{E. Strategi Pembelajaran}

1. Appersepsi, dilanjutkan dengan penjelasan tentang kompetensi dasar yang ingin dicapai dalam perkuliahan.

2. Menjelaskan pengertian / konsep masing-masing teori belajar.

3. Memberikan tugas diskusi kelompok kepada mahasiswa untuk membahas dan mengidentifikasi asumsi dasar, karakteristik dan prinsip-prinsip belajarmenurut masing-masing teori belajar utama. Kemudian dilanjutkan dengan presentasi masing-masing kelompok di dalam sebuah diskusi kelas untuk menyampaikan hasil diskusinya

4. Menugaskan mahasiswa membuat rangkuman tentang asumsi dasar, karakteristik, dan prinsip-prinsip belajar menurut masing-masing teori belajar utama

5. Menyajikankesimpulan dengan mengajak semua mahasiswa mengemukakan pendapatnya. Kemudian, dosen menyempurnakan kalau masih ada yang perlu disempurnakan. Tapi, kalau sudah pas kesimpulan yang dikemukakan mahasiswa, langsung apa yang disampaikan/ dikemukakan tersebut dijadikan kesimpulan perkuliahan.

\section{F. Media/Alat Pembelajaran}

Untuk mendukung lancarnya Kegiatan Belajar Mengajar/Perkuliahan, digunakan media/alat berupa : 
a. LCD (IN FOCUS);

b. Lembaran Kerja untuk mhs menuliskan hasil kerja kelompok kecil,

c. Lembaran Kerja untuk mencatat hasil diskusi antar kelompok,

d. Lembaran Kerja untuk rangkuman pribadi mahasiswa.

\section{G. Sistem Penilaian (Evaluasi)}

1. Penilaian di akhir perkuliahan dilakukan dalam bentuk pertanyaan lisan

a. Kemukakan masing-masing teori belajar utama!

b. Sebutkan dua orang tokoh teori belajar asosiasi!

c. Jelaskan prinsip-prinsip belajar gestalt !

d. Dst... nya

2. Penilaian pada tengah semester atau di akhir semester, dilaksanakan secara tertulis, sebagai berikut:

a. Terdapat tiga kelompok teori belajar utama yang erat hubungannya dengan permasalahan belajar mengajar. Jelaskan pengertian dan karakteristik masing-masing secara singkat!

b. Teori belajar dilandasi oleh asumsi dasar sendiri-sendiri. Bandingkan asumsi dasar teori belajar Behavioristik (asosiasi) dan teori Humanistik!

3. Teori Perkembangan Kognitif Jean Piaget erat hubungannya dengan pengembangan kurikulum/ pembelajaran. Kemukakanlah fase-fase perkembangan intelektual menurut teori perkembangan kognitif, dan jelaskan secara singkat bagaimana keterkaitannya dengan pengembangan kurikulum !

\section{H. Referensi}

a. Buku-Buku Wajib:

1). Curriculum; Principles and Foundations by: Robert S.Zais, Harper\& Row, Publisher, New York (1976).

2). Asas-Asas Kurikulum, by: S.Nasution, Bandung, Jemmars, (1990).

3). Pengembangan Kurikulum: Teori dan Praktek by: Nana Syaodih Sukmadinata, Remaja Rosdakarya, Bandung, (1997).

b. Buku-Buku Anjuran:

1). Pengembangan Kurikulum, by: S. Nasution, Alumni, Bandung (1988).

2). Dasar-Dasar Pengembangan Kurikulum, by: Iskandar Wiryokusumo \& Usman Mulyadi, Bina Aksara Jakarta (1988). .

\section{KEPUSTAKAAN ACUAN}

Brady, Laurie,Curriculum Development, New York: Prentice Hall,1992.

Hamalik, Oemar,Model-Model Pengembangan Kurikulum, Bandung: PPs UPI Bandung, 2011. 
Miller, J. P and Seller, W.,Curriculum: Syafruddin Nurdin,Pengembangan Kurikulum, Perspectives and Practices, New York: Silabus dan SAP di PTAI. Makalah: Longman, In, 1985. Disampaikan dalam Workshop Kurikulum

Nasution, S.,Asas-Asas Kurikulum,Bandung: Dosen STAI-Solok Nan Indah, 2014. Jemmars, 1990.

Rusman,Manajemen Kurikulum,Jakarta: Rajawali Pers, 2009. 